\title{
Usage of Si, P, Se, and Ca Decrease Arsenic Concentration/Toxicity in Rice, a Review
}

\author{
Mohammad Reza Boorboori *(D), Yujie Gao, Hao Wang and Changxun Fang *(D)
}

check for updates

Citation: Boorboori, M.R.; Gao, Y.; Wang, H.; Fang, C. Usage of Si, P, Se, and Ca Decrease Arsenic Concentration/Toxicity in Rice, a Review. Appl. Sci. 2021, 11, 8090. https://doi.org/10.3390/app11178090

Academic Editors: Dibyendu Sarkar and Jayanta Kumar Biswas

Received: 30 July 2021

Accepted: 29 August 2021

Published: 31 August 2021

Publisher's Note: MDPI stays neutral with regard to jurisdictional claims in published maps and institutional affiliations.

Copyright: (c) 2021 by the authors. Licensee MDPI, Basel, Switzerland. This article is an open access article distributed under the terms and conditions of the Creative Commons Attribution (CC BY) license (https:// creativecommons.org/licenses/by/ $4.0 /)$.
Fujian Provincial Key Laboratory of Agroecological Processing and Safety Monitoring, College of Life Sciences, Fujian Agriculture and Forestry University, Fuzhou 350002, China; yjechogao@fafu.edu.cn (Y.G.); wanghao@fafu.edu.cn (H.W.)

* Correspondence: m.boorboori@yahoo.com (M.R.B.); fcx007@fafu.edu.cn (C.F.)

Keywords: rice; arsenic; silicon; phosphorus; selenium; calcium

\section{Introduction}

Agriculture is currently facing the challenge of providing adequate food for a growing population [1]. Rice is a staple food worldwide [2], and it provides two-thirds of the calories needed for two billion people in Asia; while also being the primary protein source for those people [3,4]. Different types of rice provide essential elements, vitamins, nutrients, and fibre for the human body [5]. However, rice is one of the most widely consumed plants globally and requires a constant water source through irrigation, and plants consume about $60 \%$ of the irrigation water. Soil texture affects the uptake and growth of plant nutrients because it alters access to water in the soil $[1,6,7]$. One of the most important threats to natural and human ecosystems is the pollution of water and soil resources by heavy metals and metals, which causes fundamental changes in ecosystems while their entry into the biological cycle can have devastating environmental effects [8,9]. Recently, contamination of soils and groundwater with heavy metals has become a serious problem. They harm crop production worldwide [10,11], and also, contaminated soil harms economic growth and development due to the negative effects on agricultural products [12,13]. In the present study, we attempted to learn more about arsenic, the harm it causes and the ways it penetrates the rice plant as well as the effect of two micro and two macronutrients in reducing the absorption and toxicity of arsenic as a way to increase the quality of rice production and ultimately improve human health. 


\subsection{Arsenic (As) and Rice}

Arsenic is a carcinogenic metalloid, and humans are contaminated mainly through diet and drinking water., increasing health problems [14]. The National Toxicology Program and International Agency for Research on Cancer categorized arsenic as the first carcinogenic agent $[15,16]$. There are various species of As in nature, and they are listed in Table 1. More than other grains, rice accumulates arsenic in its tissues [17]. The kinds of As in rice are mainly inorganic (iAs, including arsenate and arsenite), monomethylarsonic acid (MMA), and dimethylarsinic acid (DMA) [18]. According to research, inorganic kinds of As are more toxic than DMA and MMA [19], and under anaerobic situations, As (III) is the prevailing type in soil solutions [20].

Table 1. The list of various species of arsenic.

\begin{tabular}{|c|c|c|}
\hline Arsenic Compounds & Acronyms & Chemical Formula \\
\hline Arsenate & As $(V)$ & $\mathrm{As}\left(\mathrm{O}^{-}\right)_{3}$ \\
\hline Arsenite & As (III) & $\mathrm{O}=\mathrm{As}\left(\mathrm{O}^{-}\right)_{3}$ \\
\hline Methylarsonate & MMA & $\mathrm{CH}_{3} \mathrm{AsO}\left(\mathrm{O}^{-}\right)_{2}$ \\
\hline Dimethylarsinate & DMA & $\left(\mathrm{CH}_{3}\right)_{2} \mathrm{AsO}\left(\mathrm{O}^{-}\right)$ \\
\hline Trimethylarsin oxide & TMAO & $\left(\mathrm{CH}_{3}\right)_{3} \mathrm{AsO}$ \\
\hline Tetramethylarsonium ion & TETRA & $\left(\mathrm{CH}_{3}\right)_{4} \mathrm{As}^{+}$ \\
\hline Arsenobetain & $\mathrm{AB}$ & $\left(\mathrm{CH}_{3}\right)_{3} \mathrm{As}^{+} \mathrm{CH}_{2} \mathrm{COO}^{-}$ \\
\hline Trimethylarsoniopropionate & TMAP & $\left(\mathrm{CH}_{3}\right)_{3} \mathrm{As}^{+} \mathrm{CH}_{2} \mathrm{CH}_{2} \mathrm{COO}^{-}$ \\
\hline Arsenocholine & $\mathrm{AC}$ & $\left(\mathrm{CH}_{3}\right)_{3} \mathrm{As}^{+} \mathrm{CH}_{2} \mathrm{CH}_{2} \mathrm{O}^{-}$ \\
\hline Dimethylarsinoylacetate & DMAA & $\left(\mathrm{CH}_{3}\right)_{2}(\mathrm{O}) \mathrm{As}^{+} \mathrm{CH}_{2} \mathrm{COO}^{-}$ \\
\hline Dimethylarsinoylpropionate & DMAP & $\left(\mathrm{CH}_{3}\right)_{2}(\mathrm{O}) \mathrm{As}^{+} \mathrm{CH}_{2} \mathrm{CH}_{2} \mathrm{COO}^{-}$ \\
\hline
\end{tabular}

Nomenclature is as proposed by Francesconi and Kuehnelt [21].

Increased arsenic release from soil particles by rice occurs through competition with soil mineral adsorption sites [22]. In anaerobic environments, arsenic motility and viability are significantly increased [20]. Paddy fields are an excellent environment for increasing arsenic bioavailability - the amount of arsenic absorption is such that it can enter the rice and affect rice growth - because the rice plants are grown in flooded conditions [23]. Therefore, since arsenic has a high solubility in water, this element is the most critical pollutant [24]. Arsenic contamination has become the reason for significant health difficulties in humans and animals [25], and in India, China, Sri Lanka, Pakistan, Nepal, Bangladesh, Chile, Mexico, and Argentina, pollution of drinking water sources with arsenic is now a public health emergency [26]. In some mines in southern China's Guangdong, the soil is heavily polluted with arsenic and some other heavy metals, and according to some studies, pollution in agricultural lands around these mines has reached $344.11 \mathrm{mg} / \mathrm{kg}$, which indicates an excessive concentration of arsenic (1 to $40 \mathrm{mg} / \mathrm{kg}$ ) in the soil [27].

There are two main ways to absorb arsenic in rice: (1) As (V) as a chemical analogue of phosphate is absorbed in rice roots by the phosphate transport protein system. (2) As (III) is an analogue of silicic acid and can be absorbed via the roots of rice with the delivery systems of silicic acid (Lsi1 and Lsi2) (Figure 1) [28,29]. As mentioned, there are two main pathways for arsenic uptake by rice, so because we wanted to investigate the role of microelements and macroelements in reducing toxicity and uptake of arsenic, we looked at elements that have a common uptake pathway with arsenic. Among them, we examined two macroelements $(\mathrm{P}, \mathrm{Ca})$ and two microelements $(\mathrm{Si}, \mathrm{Se})$ that effectively reduce the toxicity and absorption of arsenic in rice.

Several methods are used to determine the bioavailability and concentration of arsenic in rice, including the in vitro digestion process to determine the bioavailability of arsenic [31] and the Meharg and Jardine [32] method to determine the concentration of arsenic in rice. 


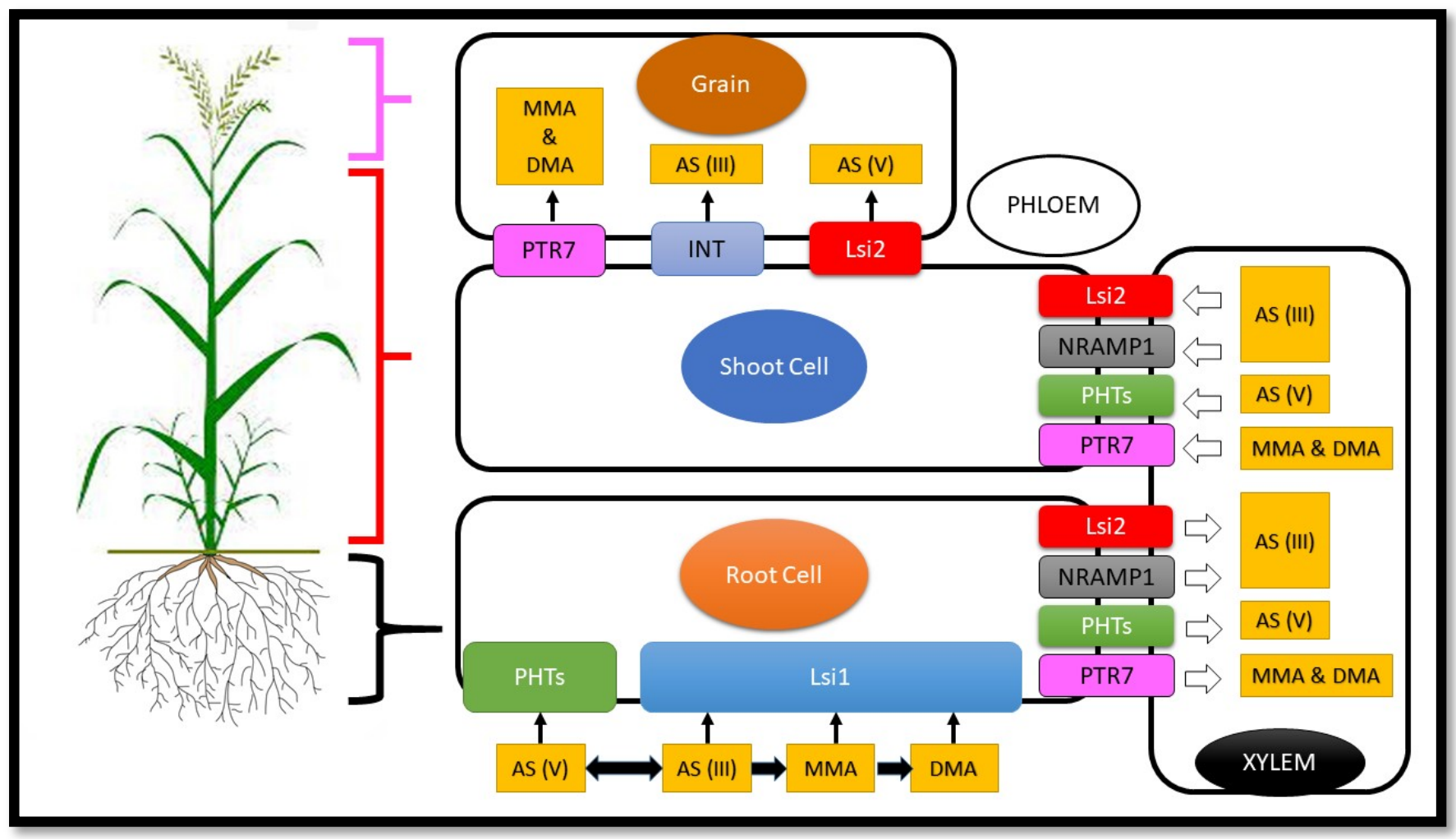

Figure 1. Mechanisms of arsenic uptake, transport, accumulation, and distribution in rice. Nomenclature is as proposed by Shinde and Kumar [30] with some modifications.

\subsection{Silicon (Si) and As}

$\mathrm{Si}$ is an essential element in the soil and crust of the earth, and soil Si content makes up 1 to $45 \%$ of soil's dry weight, but only 0.1 to $0.6 \%$ is soluble [33,34]. Si is a motionless element in plants, and rice is absorbed as ionized $\mathrm{Si}(\mathrm{OH})_{3} \mathrm{O}$ and silicic acid $\left(\mathrm{H}_{4} \mathrm{SiO}_{4}\right)$. Si content of rice's dry weight can reach up to $10 \%[35,36]$, and rice is a stacked Si plant, often used as a sample plant for Si uptake, transport, and accumulation [3]. According to research, silicon is a practical and valuable element for plant growth, especially in various stress conditions such as plant diseases, plant pests, drought, salinity [37], while one of the significant effects of $\mathrm{Si}$ is in reducing the toxicity of metal by decreasing absorption and transport of metals in plants. [38].

Studies have shown that rice roots absorb arsenite via two Si carriers, Lsi1 (the aquaporin NIP2; 1) and Lsi2 (an efflux carrier) [39]. Lsi1 is an invasive transporter responsible for transporting silicon and arsenic (III) from culture solutions to rice root cells [40]. As (III) is absorbed within cells in Escherichia coli, the yeast (Saccharomyces cerevisiae) via aquaglyceroporins and several aquaporin channels of plants are dependent on the Nodulin 26 subfamily, the same as the intrinsic protein (NIP) is permeable to As (III) in the case of heterogeneity in yeast [41,42]. The Si rice carrier Lsi1 (OsNIP2; 1) is also penetrable to As (III) expressed in Xenopus laevis and yeast oocytes [39]. The second silicon transporter (Lsi2) in rice roots transfers silicon efflux from epidermal and endodermal cells to stele to load xylem, and this transporter also mediates the efflux of As (III) [39,43].

However, adding Si to soil and water significantly decreases the concentration of arsenic in rice. In addition, some studies have shown that $\mathrm{Si}$ can help increase methylation in rice tissue and affect the concentration of different As types in rice [44]. Therefore, adding silicon to the soil can reduce As uptake and accumulation in rice, and Si foliar application may also be an alternative route to reduce arsenic accumulation in rice [22].

Different studies have been performed on the efficacy of $\mathrm{Si}$ in reducing the uptake and transport of arsenic in rice. For instance, Seyfferth and Fendorf [44] detected that the 
concentration of As in the grain was significantly reduced by adding Si to the pore water. Si application has also been reported to decrease concentrations of different types of arsenic in stem, leaf, husk, and brown rice (Figure 2) [45].

\section{As Concentration $(\mathrm{mg} / \mathrm{Kg})$}
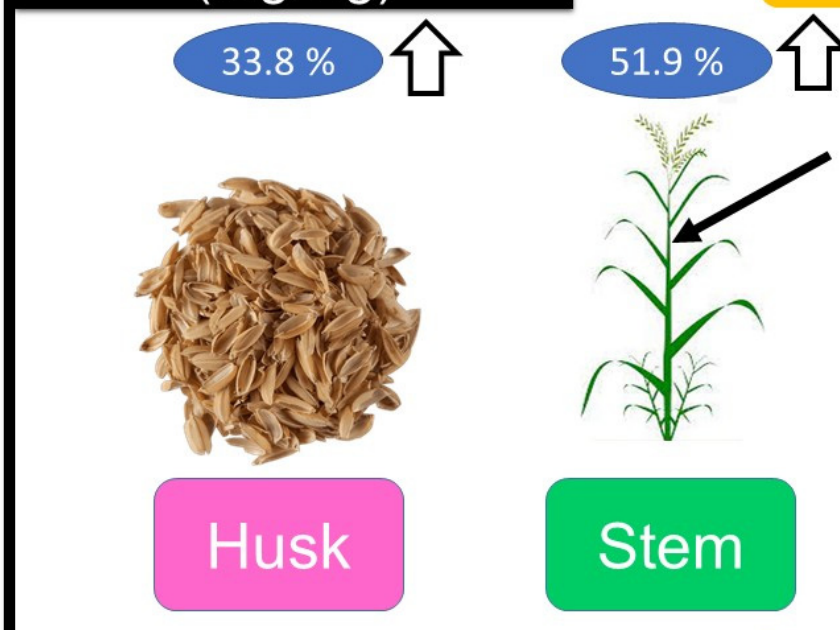

\section{$-S i$}
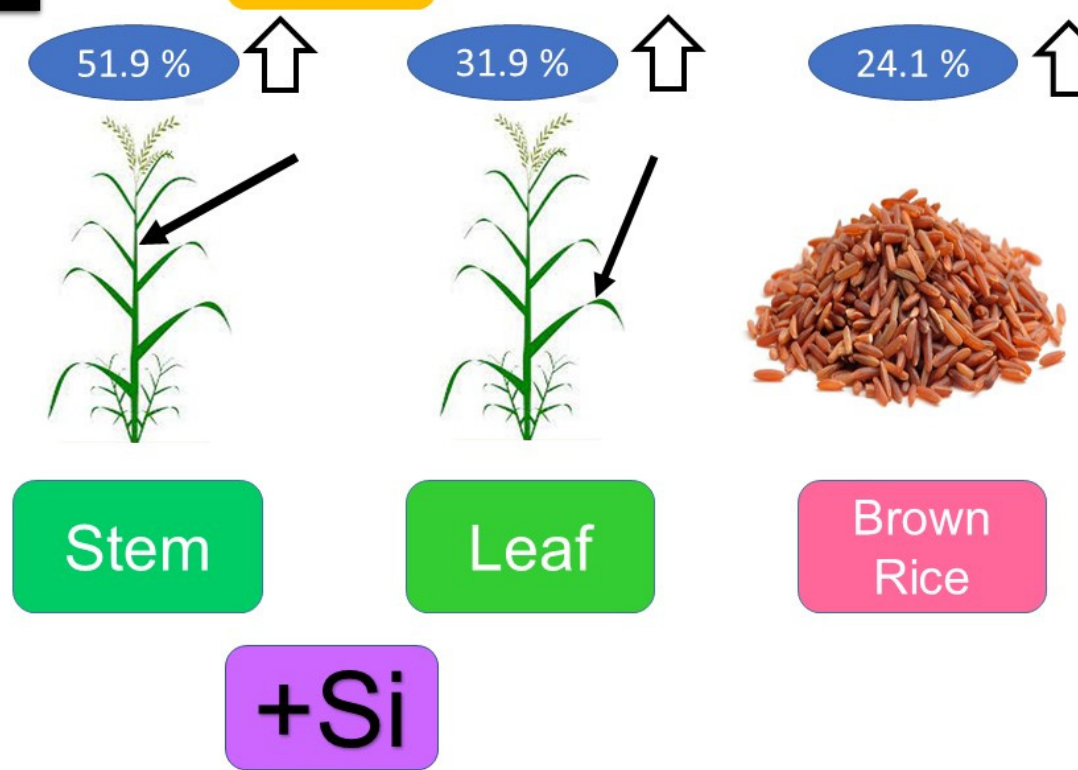

Figure 2. The effect of Adding silicon (+Si) and without silicon (-Si) treatments on arsenic concentration on different rice tissue. Nomenclature is as proposed by Gang, ZHENG [46].

It has also been observed that $\mathrm{Si}$ usage significantly decreases the concentration of iAs, while the DMA concentration increases in rice plant tissues [45]. It was found that silicic acid can also dislocate arsenite, arsenate, and Dimethylarsinate from the surface of soil particles, which increases the aggregate concentration of arsenic in the soil solution [47]. Hence, the effects of adding silicon to soil on arsenic bioavailability depend on the interactions between As and Si in pore water, particles of soil, and the absorption of rice roots [48]. According to research, to control the adverse efficacy of silicon usage in paddy soil, Si foliar usage can be a more impressive way to affect the arsenic accumulation rate in rice [22].

\subsection{Phosphorus $(P)$ and As}

Phosphorus is a vital element required for growing plants, and plants absorb it mainly as inorganic phosphate (Pi) [49]. Phosphorus plays an essential role in the biochemistry and physiology of plants, and almost all phospholipids, nucleic acids, and ATPs contain P, which is involved in regulating significant metabolic pathways and enzymatic reactions, making phosphorus essential for the worldwide production of sustainable food [50,51]. Agricultural products consume $90 \%$ of the extracted non-renewable phosphate reserves annually. As the population of the world increases and phosphate resources are depleted, it is necessary to improve the phosphorus use efficiency (PUE) at the plant and farm-wide scale $[50,52]$. Due to the high stabilization of phosphorus in the soil and its slow release to the root surface, plants have different strategies to enable phosphorus accessibility from the ground [53].

Arsenic and phosphorus are chemical analogues. However, some of the chemical properties of $\mathrm{P}$ and As, including redox reactions, are distinct and cause the biochemical behaviour of the two elements to be different. As mentioned, P is an essential plant growth 
element, while arsenic is toxic and prevents plant growth [54,55]. In the environment, arsenic occurs as arsenate or arsenite (e.g., $\mathrm{AsO}_{4}{ }^{-3}$ or $\mathrm{AsO}_{3}{ }^{-3}$ ); in contrast, phosphorus exists mainly as orthophosphate ions $\left(\mathrm{PO}_{4}^{-3}\right)$. Phosphates usually have many physicochemical properties similar to arsenates, like symmetry, acid decomposition constants, and ion size, but $\mathrm{P}$ is more susceptible to transport sites than As (V) [55-57]. In aqueous conditions, As (V) and $\mathrm{P}(\mathrm{V})$ are present as arsenates $\left(\mathrm{AsO}_{4}{ }^{-3}\right)$ and phosphate $\left(\mathrm{PO}_{4}{ }^{-3}\right)$, which are surrounded by four oxygen atoms in quadrilateral coordination. Arsenate and phosphate are assumed as chemical analogues due to their being similar chemical species, which can replace each other in chemical reactions. Biogeochemical reactions often are seen as precipitation/dissolution, adsorption/excretion, and competitive/adsorption reactions in plant and microbial systems [58-61].

Competitive processes of biogeochemical reaction between arsenate and phosphate control the arsenic bioavailability in the environment. However, arsenic oxidation reactions in the atmosphere produce various biogeochemical responses which do not occur for $\mathrm{P}$. For instance, in anaerobic conditions like rice paddies, arsenate is transformed to arsenite because it is not absorbed as much as arsenate on soil particles (especially at low or neutral $\mathrm{pH})$, so, it is more mobile and soluble. Redox mobility creates arsenic distribution in sediments and soils that decreases under fluctuations of oxidation, but $\mathrm{P}$ is not changed by redox variation [62]. An experiment on disposal of arsenate showed after using phosphate solutions, only $35 \%$ of the adsorbed arsenate was absorbed from goethite, which indicates that the arsenate bonds were more substantial than the phosphate bonds on iron oxide. The toxicity mechanism in organisms is maybe metabolic substitution of arsenate for phosphate [63].

Under aerobic conditions, As (V) and phosphorus (Pi) due to similar chemical properties, stable quadrilateral oxidants form the oxidation state p5. However, there is less correlation between the behaviour of phosphate and arsenite under aqueous conditions because phosphate is not an analogue of As (III), and arsenite transport is not affected by phosphate $[64,65]$. However, arsenite oxidation to arsenate is distinct in the rice root region [66]. Thus, the effect of phosphate on the behaviour of arsenite in the rhizosphere cannot be completely ignored, and actual cognition of this feature is needed. Unlike hydroponics, $\mathrm{P}$ usage in the soil increases arsenic uptake by the plants because of arsenic excretion [67].

Due to the essential role of phosphate in controlling the solubility of arsenic in the soil and its uptake through plants, special attention to $\mathrm{P}$ in paddy fields should be given [68]; in addition, the simultaneous usage of calcium and phosphorus forms the Ca-P-As complex and reduces mobility in enriched soils, [69]. Because As and P interactions in the soil-plant system are complicated, most studies have failed, while the variability competition between $\mathrm{P}$ and As depends on substrate conditions and soil type [70-72].

The much higher application of P may help compete for arsenic uptake in plants. In contrast, increasing the concentration of arsenic with increasing $\mathrm{P}$ in the soil solution may also increase arsenic toxicity because of As excretion in the soil solution. On the other hand, excessive P usage for the plants may also enhance the environmental risks [73]. For example, triple superphosphate (TSP) is vital among the phosphorus fertilizers, and the raw material of TSP, phosphate rock, may contain arsenic and release arsenic from solid soils into the soil solution [65].

At similar concentrations of $\mathrm{P}$ and As, arsenic is more available for uptake by the plants because of the smaller size of arsenic, and the charge of $\mathrm{P}$ ions binds to the soil with a higher intensity than As (V) [64,74]. In addition, P competes with As (V) over time because of the lower soil uptake of $\mathrm{P}$, and according to the stock charge hypothesis, ligand exchange theory, and Steindorf-Rehbon-Shintoch equation, $\mathrm{Pi}$ is more likely to be replaced by As (V) in soil $[64,75]$.

Soil properties, soil texture, soil mineralogy, and environmental factors may have a significant impact on soil availability, mobility, and interaction of $\mathrm{As}-\mathrm{Pi}$ [76], and uptake through plants, including mineral components, the presence of anions (e.g., microbial 
activity, organic matter (OM), redox potential, citrate, phosphate, $\mathrm{pH}$, phytates/phytic acid, and in particular, iron oxide and $\mathrm{Al}$ oxide/hydroxides) [77,78]. Amid these factors, $\mathrm{pH}$ and goethite firmly control the behaviour of $\mathrm{P}$ and As. Iron and magnesium-rich minerals such as phronesis smectites, nontronite, goethite, bronchitis, and pyrolusite absorb more As (V) than Pi when prepared in molar ratio. However, Pi absorbs more than As (V) in non-crystalline allergens containing allophane, boehmite, gibbsite, and clay sections (e.g., vermiculite, illite, and kaolinite) $[79,80]$. Goethite's high levels in the soil can decrease P and As uptake by plants. Adding Fe and $\mathrm{P}$ to high arsenic soils using a sequential combination method can reduce arsenic toxicity to plant roots by providing a food source [81,82].

In the presence of sandy soils and sandy loams, with $\mathrm{P}$, due to the low uptake of As (V) ions, they are displaced from the surface of the sand and increase the uptake of arsenic by plants, and as a result, this reduces plant growth. However, arsenic absorption and toxicity are reduced in sandy loam, silty loam, and clay loam soils [83-85]. High supply $\mathrm{P}$ can severely change arsenic solubility and mobility in alkaline or anion-fixing soils [80]. The adsorption and desorption of $\mathrm{Pi}$ and $\mathrm{As}(\mathrm{V})$ have similar properties and follow the Langmuir and Freundlich equations in high $\mathrm{pH}$ (calcareous purple), neutral, and low $\mathrm{pH}$ (acid) soils, but because of mobility and dissolution, and non-reactivity of $\mathrm{P}$ at low $\mathrm{pH}$ are not always interdependent - the main difference between the two models is that Langmuir assumes that ions are adsorbed as a monolayer on the surface, and maximum adsorption occurs when the surface is completely covered, while Freundlich assumes heterogeneous surfaces with which it has different affinities that have multi-layered adsorption [74,86,87]. Therefore, phosphate fertilizers, the concentration of As, and soil properties in the soil solution are the most critical factors that control the absorption of arsenic by rice in soils contaminated with As [73] (Table 2).

Competition for Fe plaque or adsorption sites in the soil between $\mathrm{PO}_{4}$ and As (V) via the ligand exchange mechanism increases arsenic bioavailability and solubility in the rhizosphere [88]. Fe plaque plays an essential role in regulating arsenic uptake in rice tissues, and other Fe plaque formation leads to arsenic sequestration at the root surface, leading to decreased arsenic uptake in brown rice [23]. It was observed that the arsenic amount in Fe plaque decreased with increasing concentration of $\mathrm{PO}_{4}$, although increasing arsenic mobility after the addition of $\mathrm{PO}_{4}$ was also reported in several other studies $[72,89,90]$. It was also reported that sufficient phosphorus leads to several Fe plaque formations in rice roots, while the lack of phosphorus in the solution increases the plaque formation in the roots. Phosphorus low concentrations in the tissues of plants can help increase oxygen transport in rice roots and stimulate the formation of Fe plaque in the roots [91]. Deformation of arsenic species occurs in Fe plaque as the root surface is regulated by microbial processes and the rhizosphere's redox environment, in which As (V) is reduced to As (III) by the arsC gene while by the aioA gene, As (III) is oxidized to As (V). Therefore, it is necessary to boost the Fe plaque formation on the rice root surface, which increases the rice's resistance to arsenic accumulation [92].

Different studies have shown that the essential factor in reducing the absorption of As (V) through the supply of $\mathrm{Pi}$ is the competitive absorption of rice roots. In addition, researchers have reported that enhancing the concentration of phosphorus in the nutrient solution reduces the uptake of As (V) through the plant $[85,93]$. Research has also shown that using high phosphate concentrations in culture solution decreases arsenic-induced damage in rice plants while increasing the amount of As (V) increases the As concentration in roots, leaves, shoots, and seeds. If As concentration decreases with increasing phosphorus [94], the plant's arsenic toxicity may therefore depend more on the ratio of As/P than the total concentration of As. A study in China also described a link between phosphorus and arsenic, and by changing the status of $\mathrm{P}$ in the shoots, accumulation of arsenic in rice grains could be reduced [95]. One study found that rice with higher internal phosphorus showed lower toxicity of As (V); therefore, expanding the application of external phosphorus helps decrease the absorption of arsenic and reduce As (V) toxicity symptoms. Two factors control $\mathrm{PO}_{4}$ efficacy on mobility and its uptake of arsenic in rice: (1) Competition 
between uptake of arsenic and phosphorus in rice roots, and (2) the essential phosphorus role in arsenic transfer from roots to shoots [73].

Table 2. Freundlich, Langmuir, and Redlich-Peterson Equations.

\begin{tabular}{|c|c|c|}
\hline Equation & Isotherm & Equation \# \\
\hline$q_{e}=K_{f} C \frac{1}{n}$ & Freundlich nonlinear & (1) \\
\hline $\log \left(q_{e}\right)=\log K_{f}+\frac{1}{n} \log C$ & Freundlich linear & (2) \\
\hline$\frac{C_{e}}{q_{e}}=\frac{1}{q_{m}} C_{e}+\frac{1}{K_{a} q_{m}}$ & Langmuir linear 1 & (3) \\
\hline$\frac{1}{q_{e}}=\left(\frac{1}{K_{a} q_{m}}\right) \frac{q_{e}}{C_{e}}$ & Langmuir linear 2 & (4) \\
\hline$q_{e}=q_{m}-\left(\frac{1}{K_{a}}\right) \frac{q_{e}}{C_{e}}$ & Langmuir linear 3 & (5) \\
\hline$\frac{q_{e}}{C_{e}}=K_{a} q_{m}-K_{a} q_{e}$ & Langmuir linear 4 & (6) \\
\hline $\begin{aligned} q_{e} & =\frac{Q_{0} K_{L} C_{e}}{1+K_{L} C_{e}} \\
R_{L} & =\frac{1}{1+K_{L} C_{0}}\end{aligned}$ & Langmuir nonlinear & $\begin{array}{l}(7) \\
(8)\end{array}$ \\
\hline$q_{e}=\frac{K_{r} C_{e}}{1+a_{r} C_{e}^{\beta}}$ & Redlich-Peterson nonlinear & (9) \\
\hline $\log \left(K_{r} \frac{C_{e}}{q_{e}}-1\right)=\beta \log \left(C_{8}\right)+\operatorname{in}\left(\alpha_{r}\right)$ & Redlich-Peterson linear & $(10)$ \\
\hline
\end{tabular}

Both arsenate and phosphate enter the plants through phosphate carriers [97], and in plants, high-affinity transporters of $\mathrm{P}$ (Phts/PTs) play an essential role in obtaining phosphorus from the soil. [98]. These P transducers are divided into four subfamilies: Pht1, Pht2, Pht3, and Pht4 [99]. Thirteen Pht1 genes were identified in the genome of rice [100], and between Pht1 genes, OsPht1;1, 1;2, 1;4, 1;6, 1;8, 1;9, and 1; 10 causes the absorption and transfer of phosphorus in rice [101]. OsPT1 is structurally expressed in rice plants for uptake and transport of $\mathrm{P}$ under $\mathrm{P}$ sufficient conditions [102], and recently it was observed that the performance of OsPht1; 4 recently facilitated uptake and mobility of $\mathrm{P}$ in rice [103]. The expression of OsPht1; 6 is involved in the uptake of $P$ under P deficiency conditions in rice roots [104], and likewise, OsPht1; 8 under P-sufficient, and P-deficiency conditions is expressed and regulated in roots [105]. OsPht1; 1, Os Pht1; 4, and OsPht1; are involved in the absorption and transport of As $(\mathrm{V})$, and their expression changes arsenic accumulation in rice [49], and eventually PTs overexpression causes P uptake, although it may also increase uptake of As by rice (Figure 1) [106,107].

\subsection{Selenium ( $\mathrm{Se}$ ) and As}

Selenium is widely spread in the earth's crust and is mainly related to sulphide minerals [108]. Until 1957, Se was known as a toxic element [109], and after that, the positive effect of selenium on human and animal health was discovered [110]; however, no evidence shows that Se is an essential element for plants [111]. Nevertheless, selenium has a vital effect on thyroid hormone metabolism, cellular metabolism, antioxidant functions, immune responses, and other minerals' uptake and accumulation regulation in humans [112]. Moreover, Se deficiency is related to health disorders, including reduced fertility, oxidative stress, accelerated aging, decreased immune function, and cancer risk increment [113].

Selenium is specifically present as seleno-L-cysteine in a multitude of selenoproteins [114]. These proteins are crucial in repairing oxidized residues and modulating oxidative stress through natural biological oxidant detoxification $[115,116]$. It has been appraised that between five hundred million and one billion of the world's population suffer from Se deficiency, but on the other hand, selenium is toxic in high concentrations, so the line between the toxicity of Se to humans and Se-deficiency is critical [113]. Plants are the primary source of Se for people worldwide [105], and recently, selenium fertilizers have been used to enhance Se in plant's edible parts [117]. Selenium comes in two forms: organic and inorganic (Table 3). Soils contain inorganic selenite and selenate that accumulate in plants and are converted to organic forms [118]. The optimal dose of Se in plants has not 
been determined, and selenium is thought to be suitable for plants that can accumulate it in high concentrations [119]. Selenium incites the growth of plants at low doses via dry matter yield addition, particularly in sulphur deficiency [120]. Also, low levels of selenium neutralize the harmful efficacies of many environmental stresses. Research has shown that low Se concentrations in plants act as antioxidants, but selenium brings oxidative damage to plant tissues in excessive doses $[117,121]$. However, Se can positively affect appropriate properties, like enhancing growth, increasing antioxidant activities capacity, increasing starch accumulation, reducing lipid peroxidation, and oxygen reactive species [122]. Therefore, Se increases essential elements, nutritional value, grain yield, and resistance to the stress of metals [123]. Several reports have shown that the external supply of Se has a positive efficacy on toleration to abiotic stress and plant growth [124].

Previous studies have reported that Se (IV) is transported to plant roots via phosphate and silicon transporters [123], and Se (VI) is transported to plant roots via sulphate transporters and may be inhibited by phosphate [125]. Rice is the primary source of selenium in the human diet, and although rice essentially requires selenium, the molecular mechanism of Se uptake is not yet well understood. Research shows that selenite is adsorbed via silicon Lsi1 (OsNIP2; 1), a silicon attack carrier in rice. Lsi1 defects lead to a significant reduction in the concentration of Se in shoots when using selenite. However, there was no difference in Se concentration between wild-type rice and Lsi1 mutant rice line when treated with selenite (Figure 1) [113].

Se is a known antagonist for arsenic toxicity, and Se is believed to detoxify arsenic plants [116]. Researchers have analysed Se efficacy application on arsenic uptake, transcript dynamics, antagonistic between arsenic and selenium in rice varieties, and antioxidant responses [126]. In the periodic table, As and Se are close to each other and play the same role in prokaryotic plant metabolic functions [127], and it should be noted that As and Se are usually paired in biochemical cycles [128]. Furthermore, studies have shown that Se and As are predominantly inorganic in paddy soils, while trace amounts of organic forms are also present because of microbial biological transmission [129].

Researchers have suggested that silicon transmitters may drive competition between As (III) and Se (IV) adsorption [113]; while As (V) and Se (IV) compete for the phosphate uptake system, arsenic (V) in general may inhibit selenium (VI) transport in vessel element [130,131]. Researchers have also shown that Se reduces As toxicity in rice via reduction of arsenic accumulation, by reducing oxidative stress through nutrient status, and increasing antioxidant efficiency [132]. A study was performed to consider the interaction between selenium and arsenic, which showed that adding As via irrigation water significantly decreased rice straw, grain yield, and roots. However, selenium assisted in reducing the detrimental efficacy of As and offset the decrease in performance due to the arsenic toxicity, while the impact of selenium was more significant on the dry yield at higher doses. The observations also showed that Se application might reduce the accumulation and toxicity in the rice crop [133]. A similar study also showed that selenium application showed a significant reduction in fluorescent nitric oxide (NO) intensity, $\mathrm{H}_{2} \mathrm{O}_{2}$ content, arsenic accumulation, reactive oxygen species (ROS), and superoxide radical $\left(\mathrm{O}_{2}{ }^{-}\right)$associated with cell death, indicating a protective role of Se in rice as a possible ROS igniter [134].

Besides, research has suggested a positive role for Se in increasing the enzymatic activity of thiol metabolism, which induces a pattern of differential accumulation of sulphurrelated genes and improves arsenic toxicity through selenium completion, including a stable balance of sulphur-containing compounds and nutrients. Furthermore, nutrient levels are positively dependent on the differential expression pattern of genes related to NPK involved in nutrient availability and metabolism [134,136]. Overall, some studies are providing new insights into the role of Se in different rice genotypes under arsenic stress via changes in thiol-related genes and nutrient transport. Of course, the researchers' new view is that Se may affect arsenic transfer to the stem, but it does not affect its uptake process [134,137]. 
Table 3. The list of different species of selenium.

\begin{tabular}{|c|c|c|}
\hline Selenium Compounds & Acronyms & Chemical Formula \\
\hline \multicolumn{3}{|l|}{ Inorganic species } \\
\hline Selenate & $\mathrm{Se}(\mathrm{VI})$ & $\mathrm{H}_{2} \mathrm{SeO}_{4}^{\circ}, \mathrm{HseO}_{4}^{-}, \mathrm{SeO}_{4}^{2-}$ \\
\hline Selenite & Se(IV) & $\mathrm{H}_{2} \mathrm{SeO}_{3}{ }^{\circ}, \mathrm{HseO}_{3}-, \mathrm{SeO}_{3}{ }^{2-}, \mathrm{SeO}_{2}$ \\
\hline Elemental Selenium & $\operatorname{Se}\left({ }^{\circ}\right)$ & $\mathrm{Se}^{\circ}$ \\
\hline Selenide & Se(-II) & $\mathrm{H}_{2} \mathrm{Se}$ \\
\hline \multicolumn{3}{|l|}{ Organic species } \\
\hline Dimethyl selenide & DMSe & $\left(\mathrm{CH}_{3}\right)_{2} \mathrm{Se}$ \\
\hline Dimethyldiselenide & DMDSe & $\left(\mathrm{CH}_{3}\right)_{2} \mathrm{Se}_{2}$ \\
\hline Dimethylseleniumsulfide & & $\left(\mathrm{CH}_{3}\right)_{2} \mathrm{SeS}$ \\
\hline Dimethylseleniumdisulfide & & $\left(\mathrm{CH}_{3}\right)_{2} \mathrm{SeS}_{2}$ \\
\hline Selenodi-glutathione & & GSSeSG \\
\hline Selenocysteine & $\mathrm{SeC}$ & $\mathrm{HSeCH}_{2} \mathrm{CHNH}_{2} \mathrm{COOH}$ \\
\hline Selenomethionine & SeM & $\mathrm{CH}_{3} \mathrm{Se}\left(\mathrm{CH}_{2}\right)_{2} \mathrm{CHNH}_{2}-\mathrm{COOH}$ \\
\hline Trimethylselenonium & & $\left(\mathrm{CH}_{3}\right)_{3} \mathrm{Se}^{-}$ \\
\hline Selenocyanate & & $\mathrm{SeCN}^{-}$ \\
\hline Selenoproteins & & \\
\hline
\end{tabular}

\subsection{Calcium ( $\mathrm{Ca}$ ) and As}

Ca is not only a necessary nutrient for plants [138], but it plays significant roles as in preventing leakage of solutes from the cytoplasm and regulating enzymatic and hormonal activity in plants $[139,140]$. Multiple kinds of research have also demonstrated that $\mathrm{Ca}^{2+}$ increases the amplification of cell walls and that sufficient levels of $\mathrm{Ca}^{2+}$ in the external environment are required to maintain cell membrane selection and integrity [138].

$\mathrm{Ca}$ is involved in metabolic processes of absorption of other nutrients and challenges other positively charged ions like $\mathrm{Mg}^{2+}, \mathrm{K}^{+}, \mathrm{Na}^{+}$; therefore, excessive use of these positively charged ions reduces Ca uptake by plants [141]. Studies have shown that high levels of $\mathrm{Ca}^{2+}$ can change the increase and removal of sodium (Na) in plant roots, which are subjected to the stress of $\mathrm{NaCl}$ [139]. In addition, roots with high levels of $\mathrm{Ca}^{2+}$ often retain their concentration of $\mathrm{K}^{+}$, while roots with low $\mathrm{Ca}^{2+}$ often cannot $[142,143]$.

Ca participates in signalling various physiological and biochemical processes as a secondary messenger that mediates some cell and plant growth perspectives and responds to the different stresses $[144,145]$. Because in stress signalling, $\mathrm{Ca}^{2+}$ is ubiquitous, it can be an essential node for cross-route discussion. Most of the stresses gain concentrations of cytosolic free Ca [146,147]. Four leading calcium-bound proteins families are known in plants: including calcium-dependent protein kinases (CDPK), calmodulin, calmodulin-like proteins, and calcineurin-like proteins B [148,149].

Recently, multitude studies have demonstrated which exogenous Ca reduces stresses in the environment, including the stress of toxic metals, by reducing metal uptake $[138,150]$ and some studies have shown that the use of calcium peroxide $\left(\mathrm{CaO}_{2}\right)$ helps reduce arsenic toxicity and mobility in soil and eliminates arsenic from water [151,152]. Nevertheless, data are limited about the effects of $\mathrm{CaO}_{2}$ on arsenic accumulation and toxicity in crops grown in As-contaminated soils. Various studies have shown that $\mathrm{CaO}_{2}$ can effectively reduce arsenic uptake by plants by reducing As mobility in the soil, but the mechanism of applying $\mathrm{CaO}_{2}$ on the dynamics of As in flooded soil and arsenic uptake through rice is as yet unknown $[153,154]$. Nevertheless, creating aerobic conditions by water management like drainage is an excellent way to decrease As accumulation in rice grains. However, drainage operations are complex in some locations with a long rainy season and poorly drained soils. In this regard, oxygen-releasing compounds (ORC) can be an alternative to maintain aerobic conditions even in paddy soils $[155,156] . \mathrm{CaO}_{2}$ is an ORC and added to water generates hydrogen peroxide $\left(\mathrm{H}_{2} \mathrm{O}_{2}\right)$ and oxygen $\left(\mathrm{O}_{2}\right)$. Due to the, chemical properties of $\mathrm{CaO}_{2}$ it has been used as an oxidant to increase organic pollutant degradation like glyphosate, toluene, and polycyclic aromatic hydrocarbons in polluted 
soil and water $[157,158]$. The research related to the effects of $\mathrm{CaO}_{2}$ on the accumulation of As in rice plants showed that in the growth in As-contaminated paddy soils, As distribution and concentration in the pore water of all soils tested decreased using $\mathrm{CaO}_{2}$. In brown rice, treatment of low-level arsenic in soil and $\mathrm{CaO}_{2}$ increased grain yield and reduced inorganic arsenic concentration; however, in soils enriched with arsenic, the proposed $\mathrm{CaO}_{2}$ application method is not practical [156].

Another study on the efficacy of exogenous calcium $\left(\mathrm{CaCl}_{2}\right)$ on antioxidant and glyoxalase systems of rice seedlings grown under As stress showed that $\mathrm{CaCl}_{2}$ in combination with different levels of As significantly decreased As accumulation and plant growth restoration in rice plants. Ca application on arsenic exposed rice seedlings decreased the production of ROS. However, it enhanced activities of ascorbate content (ASA), dehydroascorbate reductase (DHAR), glyoxalase I (Gly I), glyoxalase II (Gly II), monohydric ascorbate reductase (MDHAR), superoxide (SOD), catalase (CAT), and glutathione peroxidase (GPX) compared with seedlings that were only exposed to As [159]. Thus, both $\mathrm{Ca}^{2+}$ and ROS signalling positively correlated under environmental stress [138,160].

Various studies have shown that the combination of calcium with other elements and compounds significantly affects the levels of arsenic contamination in rice plants. For example, a study showed that the interaction between calcium $\left(\mathrm{Ca}^{2+}\right)$ and melatonin (Mel) effectively increased the endurance of metal toxicity, although the physiological and biochemical mechanisms of that are still unclear [161]. Under arsenic toxicity conditions, $\mathrm{Ca}^{2+}$ and Mel applications synergistically suppressed the cell death characteristics of the plant (nucleation density and nucleus fragmentation) in stomatal protective cells, ROS formation, and DNA damage in protective roots, leaves, and cells. In addition, the results showed that the use of $\mathrm{Mel}$ with $\mathrm{Ca}^{2+}$ increased the resistance to arsenic toxicity by increasing the enzymes involved in the antioxidant system, the regulation of plasma membrane activity of plasma $\mathrm{H}^{+}$-ATPase, and the ascorbate-glutathione pathway $[138,160]$.

In another experiment, the CF compound including $90 \%$ calcium sulphate $\left(\mathrm{CaSO}_{4}\right)$ and $10 \%$ ferric oxide $\left(\mathrm{Fe}_{2} \mathrm{O}_{3}\right)$, significantly decreased the arsenic concentration in soil solution and rice grains [162]. Other experiments on a Ca-based magnetic biochar (Ca$\mathrm{MBC})$, made by pyrolysis of a mixture of rice straw, iron oxide $\left(\mathrm{Fe}_{2} \mathrm{O}_{3}\right)$, and calcium carbonate $\left(\mathrm{CaCO}_{3}\right)$, showed that $\mathrm{Ca}-\mathrm{MBC}$ at the optimum $\mathrm{pH}(\mathrm{pH}$ ) was absorbed As (III) (15-33\%) in contaminated water and soil significantly and reduced As contamination within $12 \mathrm{~h}$ and generally reduced rice As-contamination [163].

\section{Conclusions}

The present study investigated the bioavailability, bio-pollution, uptake, accumulation, and toxicity of arsenic in rice and the cost-effective fertilizers that can reduce the uptake and transport of arsenic in rice. Among the inorganic species As, as As (III) is more toxic than As (V). Studies have shown that significant amounts of As can be transmitted to rice shoots and grains depending on the genotype and soil conditions. Arsenite and methylated organic species enter rice using the Si and P transport routes. The use of Si in rice fields reduces the concentration of arsenite in rice. Although the use of Si by removing it from soil particles can increase the bioavailability of As, due to the common pathway of these two elements, when $\mathrm{Si}$ is added to the culture medium, the competition between them increases and thus reduces the As uptake by the rice. Phosphorus is the chemical analogue of arsenic, and it can control As soil motility and As uptake in rice through competing for soil particle uptake sites, by competition between $\mathrm{PO}_{4}$ and $\mathrm{As}$ for uptake, and the opposing effect of $\mathrm{PO}_{4}$ on root-to-shoot As transfer.

Se (IV) is transported to plant roots via phosphate and silicon transporters, and Se (VI) is transported to plant roots via sulphate transporters, and then competes with arsenic through the known routes. However, the exact mechanisms of uptake, transport, and competition with As are not fully understood, and more detailed studies are needed to understand these mechanisms. Ca participates in signalling various physiological and biochemical processes as a secondary messenger that mediates several cell and plant growth prospects and responds 
to various stresses. This can be an excellent alternative to decrease As toxicity; however, the effect of $\mathrm{Ca}$ on rice resistance to arsenic requires further research.

The use of fertilizers for plant nutrition can be a way to reduce various environmental stresses in rice plants. The present study provides an overview of the effect of two microelements and two macro-elements on the uptake and toxicity of arsenic, and as mentioned, further studies are needed to identify the exact uptake pathways of these elements as well as to increase their effect on arsenic toxicity in rice.

Funding: This work was supported by the Outstanding Youth Scientific Fund of Fujian Agriculture and Forestry University (xjq201805), the Open Project Program of Guangdong Provincial Key Laboratory of Eco-circular Agriculture, the Foundation for the Science and Technology Innovation of Fujian Agriculture and Forestry University (CXZX2018042, CXZX2017309), the Foundation of Institute of Modern Seed Industrial Engineering.

Institutional Review Board Statement: Not applicable.

Informed Consent Statement: Not applicable.

Data Availability Statement: Not applicable.

Acknowledgments: This work was supported by the Outstanding Youth Scientific Fund of Fujian Agriculture and Forestry University (xjq201805), the Open Project Program of Guangdong Provincial Key Laboratory of Eco-circular Agriculture, the Foundation for the Science and Technology Innovation of Fujian Agriculture and Forestry University (CXZX2018042, CXZX2017309).

Conflicts of Interest: The authors declare no conflict of interest.

\section{References}

1. Alhaj Hamoud, Y.; Wang, Z.; Guo, X.; Shaghaleh, H.; Sheteiwy, M.; Chen, S.; Qiu, R.; Elbashier, M. Effect of irrigation regimes and soil texture on the potassium utilization efficiency of rice. Agronomy 2019, 9, 100. [CrossRef]

2. Liang, Y.; Nan, W.; Qin, X.; Zhang, H. Field performance on grain yield and quality and genetic diversity of overwintering cultivated rice (Oryza sativa L.) in southwest China. Sci. Rep. 2021, 11, 1-16.

3. Kim, Y.-H.; Khan, A.L.; Shinwari, Z.K.; Kim, D.-H.; Waqas, M.; Kamran, M.; Lee, I.-J. Silicon treatment to rice (Oryza sativa L. cv.'Gopumbyeo') plants during different growth periods and its effects on growth and grain yield. J. Pak. J. Bot. $2012,44,891-897$.

4. Mitani, N.; Ma, J.F. Uptake system of silicon in different plant species. J. Exp. Bot. 2005, 56, 1255-1261. [CrossRef]

5. Maione, C.; Barbosa, R.M. Recent applications of multivariate data analysis methods in the authentication of rice and the most analyzed parameters: A review. Crit. Rev. Food Sci. Nutr. 2019, 59, 1868-1879. [CrossRef] [PubMed]

6. Adarsh, S.; Thomas, G. Artificial groundwater recharge through rice (Oryza sativa L.) cultivation: A systematic review. Int. J. Chem. Stud. 2019, 7, 1856-1860.

7. Arunrat, N.; Pumijumnong, N.; Sereenonchai, S.; Chareonwong, U.; Wang, C. Assessment of climate change impact on rice yield and water footprint of large-scale and individual farming in Thailand. Sci. Total Environ. 2020, 726, 137864. [CrossRef]

8. Bhattacharya, P.; Samal, A.; Majumdar, J.; Santra, S. Accumulation of arsenic and its distribution in rice plant (Oryza sativa L.) in Gangetic West Bengal, India. J. Paddy Water Environ. 2010, 8, 63-70. [CrossRef]

9. Bhattacharya, S.; Gupta, K.; Debnath, S.; Ghosh, U.C.; Chattopadhyay, D.; Mukhopadhyay, A. Arsenic bioaccumulation in rice and edible plants and subsequent transmission through food chain in Bengal basin: A review of the perspectives for environmental health. J. Toxicol. Environ. Chem. 2012, 94, 429-441. [CrossRef]

10. Raza, M.M.; Ullah, S.; Ahmad, Z.; Saqib, S.; Ahmad, S.; Bilal, H.M.; Wali, F. Silicon mediated arsenic reduction in rice by limiting its uptake. J. Agric. Sci. China 2016, 7, 1.

11. Dey, T.K.; Banerjee, P.; Bakshi, M.; Kar, A. Groundwater arsenic contamination in West Bengal: Current scenario, effects and probable ways of mitigation. J. Int. Lett. Nat. Sci. 2014, 8, 45-58. [CrossRef]

12. Farquhar, G.D.; Buckley, T.N.; Miller, J.M. Optimal stomatal control in relation to leaf area and nitrogen content. J. Silva Fennica. 2002, 36, 625-637. [CrossRef]

13. Huq, S.I.; Joardar, J.; Parvin, S.; Correll, R.; Naidu, R. Arsenic contamination in food-chain: Transfer of arsenic into food materials through groundwater irrigation. J. Health Popul. 2006, 24, 305.

14. Cui, J.; Shi, J.; Jiang, G.; Jing, C. Arsenic levels and speciation from ingestion exposures to biomarkers in Shanxi, China: Implications for human health. Environ. Sci. Technol. 2013, 47, 5419-5424. [CrossRef]

15. Jørgensen, K.; Larsen, E.H.; Petersen, A.; Lund, K.H.; Hilbert, G.; Andersen, N.L.; Hallas-Møller, T.; Larsen, J.C. Chemical contaminants. Food Monit. 1993, 1997, 133.

16. Bahler, D.; Stone, B.; Wellington, C.; Bristol, D.W. Symbolic, neural, and Bayesian machine learning models for predicting carcinogenicity of chemical compounds. J. Chem. Inf. Comput. Sci. 2000, 40, 906-914. [CrossRef] 
17. Williams, P.N.; Villada, A.; Deacon, C.; Raab, A.; Figuerola, J.; Green, A.J.; Feldmann, J.; Meharg, A.A. Greatly enhanced arsenic shoot assimilation in rice leads to elevated grain levels compared to wheat and barley. Environ. Sci. Technol. 2007, 41, 6854-6859. [CrossRef]

18. Nookabkaew, S.; Rangkadilok, N.; Mahidol, C.; Promsuk, G.; Satayavivad, J. Determination of arsenic species in rice from Thailand and other Asian countries using simple extraction and HPLC-ICP-MS analysis. J. Agric. Food Chem. 2013, 61, 6991-6998. [CrossRef]

19. Calatayud, M.; Bralatei, E.; Feldmann, J.; Devesa, V.; Vélez, D. Transformation of arsenic species during in vitro gastrointestinal digestion of vegetables. J. Agric. Food Chem. 2013, 61, 12164-12170. [CrossRef]

20. Xu, X.; McGrath, S.; Meharg, A.; Zhao, F. Growing rice aerobically markedly decreases arsenic accumulation. Environ. Sci. Technol. 2008, 42, 5574-5579. [CrossRef]

21. Francesconi, K.A.; Kuehnelt, D. Determination of arsenic species: A critical review of methods and applications, $2000-2003$. Analyst 2004, 129, 373-395. [CrossRef]

22. Zhang, S.; Geng, L.; Fan, L.; Zhang, M.; Zhao, Q.; Xue, P.; Liu, W. Spraying silicon to decrease inorganic arsenic accumulation in rice grain from arsenic-contaminated paddy soil. Sci. Total Environ. 2020, 704, 135239. [CrossRef] [PubMed]

23. Pan, W.; Wu, C.; Xue, S.; Hartley, W. Arsenic dynamics in the rhizosphere and its sequestration on rice roots as affected by root oxidation. J. Environ. Sci. 2014, 26, 892-899. [CrossRef]

24. Pinto, A.; Mota, A.D.; De Varennes, A.; Pinto, F. Influence of organic matter on the uptake of cadmium, zinc, copper and iron by sorghum plants. J. Sci. Total Environ. 2004, 326, 239-247. [CrossRef] [PubMed]

25. Chowdhury, T.R.; Basu, G.K.; Mandal, B.K.; Biswas, B.K.; Samanta, G.; Chowdhury, U.K.; Chanda, C.R.; Lodh, D.; Roy, S.L.; Saha, K.C. Arsenic poisoning in the Ganges delta. J. Nat. 1999, 401, 545-546. [CrossRef]

26. Petrusevski, B.; Sharma, S.; Schippers, J.C.; Shordt, K. Arsenic in drinking water. J. Delft IRC Int. Water Sanit. Cent. 2007, 17, 36-44.

27. Mandal, B.K.; Suzuki, K.T. Arsenic round the world: A review. Talanta 2002, 58, 201-235. [CrossRef]

28. Wu, C.; Zou, Q.; Xue, S.; Mo, J.; Pan, W.; Lou, L.; Wong, M.H. Effects of silicon (Si) on arsenic (As) accumulation and speciation in rice (Oryza sativa L.) genotypes with different radial oxygen loss (ROL). J. Chemosphere 2015, 138, 447-453. [CrossRef]

29. Zhao, F.-J.; Zhu, Y.-G.; Meharg, A.A. Methylated arsenic species in rice: Geographical variation, origin, and uptake mechanisms. J. Environ. Sci. Technol. 2013, 47, 3957-3966. [CrossRef] [PubMed]

30. Shinde, A.; Kumar, K. Mechanisms of Arsenic Transport, Accumulation, and Distribution in Rice. In Arsenic Toxicity: Challenges and Solutions; Springer: Berlin/Heidelberg, Germany, 2021; p. 279.

31. He, Y.; Pedigo, C.E.; Lam, B.; Cheng, Z.; Zheng, Y. Bioaccessibility of arsenic in various types of rice in an in vitro gastrointestinal fluid system. J. Environ. Sci. Health Part B 2012, 47, 74-80. [CrossRef]

32. Meharg, A.A.; Jardine, L. Arsenite transport into paddy rice (Oryza sativa) roots. New Phytol. 2003, 157, 39-44. [CrossRef]

33. Cuong, T.X.; Ullah, H.; Datta, A.; Hanh, T.C. Effects of silicon-based fertilizer on growth, yield and nutrient uptake of rice in tropical zone of Vietnam. J. Rice Sci. 2017, 24, 283-290. [CrossRef]

34. Song, Z.; Wang, H.; Strong, P.J.; Shan, S. Increase of available soil silicon by Si-rich manure for sustainable rice production. J. Agron. Sustain. Dev. 2014, 34, 813-819. [CrossRef]

35. Ma, J.; Miyake, Y.; Takahashi, E. Silicon as a beneficial element for crop plants. Stud. Plant Sci. 2001, 8, 17-39.

36. Pontigo, S.; Godoy, K.; Jiménez, H.; Gutiérrez-Moraga, A.; Mora, M.D.L.L.; Cartes, P. Silicon-mediated alleviation of aluminum toxicity by modulation of $\mathrm{Al} / \mathrm{Si}$ uptake and antioxidant performance in ryegrass plants. J. Front. Plant Sci. 2017, 8, 642. [CrossRef]

37. Liang, Y.; Wong, J.; Wei, L. Silicon-mediated enhancement of cadmium tolerance in maize (Zea mays L.) grown in cadmium contaminated soil. Chemosphere 2005, 58, 475-483. [CrossRef]

38. Fleck, A.T.; Mattusch, J.; Schenk, M.K. Silicon decreases the arsenic level in rice grain by limiting arsenite transport. J. Plant Nutr. 2013, 176, 785-794. [CrossRef]

39. Ma, J.F.; Yamaji, N.; Mitani, N.; Xu, X.-Y.; Su, Y.-H.; McGrath, S.P.; Zhao, F.-J. Transporters of arsenite in rice and their role in arsenic accumulation in rice grain. Proc. Natl. Acad. Sci. USA 2008, 105, 9931-9935. [CrossRef]

40. Li, R.-Y.; Ago, Y.; Liu, W.-J.; Mitani, N.; Feldmann, J.; McGrath, S.P.; Ma, J.F.; Zhao, F.-J. The rice aquaporin Lsi1 mediates uptake of methylated arsenic species. Plant Physiol. 2009, 150, 2071-2080. [CrossRef]

41. Bhattacharjee, H.; Rosen, B.P. Arsenic metabolism in prokaryotic and eukaryotic microbes. In Molecular Microbiology of Heavy Metals; Springer: Berlin/Heidelberg, Germany, 2007; pp. 371-406.

42. Bhattacharjee, H.; Mukhopadhyay, R.; Thiyagarajan, S.; Rosen, B.P. Aquaglyceroporins: Ancient channels for metalloids. J. Biol. 2008, 7, 1-6. [CrossRef] [PubMed]

43. Ma, J.F.; Yamaji, N.; Tamai, K.; Mitani, N. Genotypic difference in silicon uptake and expression of silicon transporter genes in rice. J. Plant Physiol. 2007, 145, 919-924. [CrossRef] [PubMed]

44. Seyfferth, A.L.; Fendorf, S. Silicate mineral impacts on the uptake and storage of arsenic and plant nutrients in rice (Oryza sativa L.). J. Environ. Sci. Technol. 2012, 46, 13176-13183. [CrossRef]

45. Liu, W.-J.; McGrath, S.P.; Zhao, F.-J. Silicon has opposite effects on the accumulation of inorganic and methylated arsenic species in rice. J. Plant Soil 2014, 376, 423-431. [CrossRef]

46. Gang, L.; Zheng, M.; Tang, J.; Hojae, S.; Chao, C. Effect of silicon on arsenic concentration and speciation in different rice tissues. Pedosphere 2018, 28, 511-520. 
47. Lee, C.-H.; Huang, H.-H.; Syu, C.-H.; Lin, T.-H.; Lee, D.-Y. Increase of As release and phytotoxicity to rice seedlings in Ascontaminated paddy soils by Si fertilizer application. J. Hazard. Mater. 2014, 276, 253-261. [CrossRef]

48. Syu, C.-H.; Huang, C.-C.; Jiang, P.-Y.; Chien, P.-H.; Wang, H.-Y.; Su, J.-Y.; Lee, D.-Y. Effects of foliar and soil application of sodium silicate on arsenic toxicity and accumulation in rice (Oryza sativa L.) seedlings grown in As-contaminated paddy soils. Soil Sci. Plant Nutr. 2016, 62, 357-366. [CrossRef]

49. Cao, Y.; Sun, D.; Chen, J.-X.; Mei, H.; Ai, H.; Xu, G.; Chen, Y.; Ma, L.Q. Phosphate transporter PvPht1; 2 enhances phosphorus accumulation and plant growth without impacting arsenic uptake in plants. Environ. Sci. Technol. 2018, 52, 3975-3981. [CrossRef]

50. Cordell, D.; Drangert, J.-O.; White, S. The story of phosphorus: Global food security and food for thought. Glob. Environ. Chang. 2009, 19, 292-305. [CrossRef]

51. Rose, T.J.; Impa, S.; Rose, M.; Pariasca-Tanaka, J.; Mori, A.; Heuer, S.; Johnson-Beebout, S.; Wissuwa, M. Enhancing phosphorus and zinc acquisition efficiency in rice: A critical review of root traits and their potential utility in rice breeding. Ann. Bot. 2013, 112, 331-345. [CrossRef]

52. Simpson, R.J.; Oberson, A.; Culvenor, R.A.; Ryan, M.H.; Veneklaas, E.J.; Lambers, H.; Lynch, J.P.; Ryan, P.R.; Delhaize, E.; Smith, F.A. Strategies and agronomic interventions to improve the phosphorus-use efficiency of farming systems. Plant Soil 2011, 349, 89-120. [CrossRef]

53. Wu, P.; Shou, H.; Xu, G.; Lian, X. Improvement of phosphorus efficiency in rice on the basis of understanding phosphate signaling and homeostasis. Curr. Opin. Plant Biol. 2013, 16, 205-212. [CrossRef]

54. Farooq, M.A.; Islam, F.; Ali, B.; Najeeb, U.; Mao, B.; Gill, R.A.; Yan, G.; Siddique, K.H.; Zhou, W. Arsenic toxicity in plants: Cellular and molecular mechanisms of its transport and metabolism. Environ. Exp. Bot. 2016, 132, 42-52. [CrossRef]

55. Strawn, D.G. Review of interactions between phosphorus and arsenic in soils from four case studies. Geochem. Trans. 2018, 19, 1-13. [CrossRef]

56. Beever, R.E.; Burns, D. Phosphorus uptake, storage and utilization by fungi. In Advances in Botanical Research; Elsevier: Amsterdam, The Netherlands, 1981; Volume 8, pp. 127-219.

57. Dunlop, J.; Phung, H.; Meeking, R.; White, D. The kinetics associated with phosphate absorption by Arabidopsis and its regulation by phosphorus status. Funct. Plant Biol. 1997, 24, 623-629. [CrossRef]

58. Neupane, G.; Donahoe, R.J.; Arai, Y. Kinetics of competitive adsorption/desorption of arsenate and phosphate at the ferrihydritewater interface. Chem. Geol. 2014, 368, 31-38. [CrossRef]

59. Rivas-Pérez, I.M.; Paradelo-Núñez, R.; Nóvoa-Muñoz, J.C.; Arias-Estévez, M.; Fernández-Sanjurjo, M.J.; Álvarez-Rodríguez, E.; Núñez-Delgado, A. As (V) and P competitive sorption on soils, by-products and waste materials. Int. J. Environ. Res. Public Health 2015, 12, 15706-15715. [CrossRef]

60. Senn, A.-C.; Hug, S.J.; Kaegi, R.; Hering, J.G.; Voegelin, A. Arsenate co-precipitation with Fe(II) oxidation products and retention or release during precipitate aging. Water Res. 2018, 131, 334-345. [CrossRef]

61. Anawar, H.M.; Rengel, Z.; Damon, P.; Tibbett, M. Arsenic-phosphorus interactions in the soil-plant-microbe system: Dynamics of uptake, suppression and toxicity to plants. Environ. Pollut. 2018, 233, 1003-1012. [CrossRef]

62. Sanz, E.; Munoz-Olivas, R.; Camara, C.; Sengupta, M.K.; Ahamed, S. Arsenic speciation in rice, straw, soil, hair and nails samples from the arsenic-affected areas of Middle and Lower Ganga plain. J. Environ. Sci. Health Part A 2007, 42, 1695-1705. [CrossRef]

63. Tripathi, R.; Tripathi, P.; Dwivedi, S.; Dubey, S.; Chakrabarty, D.; Trivedi, P. Arsenomics: Omics of arsenic metabolism in plants. Front. Physiol. 2012, 3, 275. [CrossRef] [PubMed]

64. Lambkin, D.; Alloway, B. Arsenate-induced phosphate release from soils and its effect on plant phosphorus. Water Air Soil Pollut. 2003, 144, 41-56. [CrossRef]

65. Quader, I.S.B. Effect of Arsenic, Nitrogen and Phosphorus on Growth and Yield of Rice. Doctoral Dissertation, Department of Soil Science, Sher-e-Bangla Agricultural University, Dhaka, Bangladesh, 2017.

66. Armstrong, W. Oxygen diffusion from the roots of some British bog plants. Nature 1964, 204, 801-802. [CrossRef]

67. Bolan, N.; Mahimairaja, S.; Kunhikrishnan, A.; Choppala, G. Phosphorus-arsenic interactions in variable-charge soils in relation to arsenic mobility and bioavailability. Sci. Total Environ. 2013, 463, 1154-1162. [CrossRef]

68. Fitz, W.J.; Wenzel, W.W. Arsenic transformations in the soil-rhizosphere-plant system: Fundamentals and potential application to phytoremediation. J. Biotechnol. 2002, 99, 259-278. [CrossRef]

69. Neupane, G.; Donahoe, R.J. Calcium-phosphate treatment of contaminated soil for arsenic immobilization. Appl. Geochem. 2013, 28, 145-154. [CrossRef]

70. Szegedi, K.; Vetterlein, D.; Jahn, R. Modelling rhizosphere transport in the presence of goethite, including competitive uptake of phosphate and arsenate. Plant Soil 2010, 330, 481-501. [CrossRef]

71. Peryea, F. Phosphate starter fertilizer temporarily enhances soil arsenic uptake by apple trees grown under field conditions. Hortscience 1998, 33, 826-829. [CrossRef]

72. Geng, C.-N.; Zhu, Y.-G.; Liu, W.-J.; Smith, S.E. Arsenate uptake and translocation in seedlings of two genotypes of rice is affected by external phosphate concentrations. Aquat. Bot. 2005, 83, 321-331. [CrossRef]

73. Lee, C.-H.; Wu, C.-H.; Syu, C.-H.; Jiang, P.-Y.; Huang, C.-C.; Lee, D.-Y. Effects of phosphorous application on arsenic toxicity to and uptake by rice seedlings in As-contaminated paddy soils. Geoderma 2016, 270, 60-67. [CrossRef]

74. Zou, Q.; Liu, F.; Yang, J.-H. Adsorption-desorption and competitive adsorption of arsenic and phosphorus in purple soil. Ying Yong Sheng Tai Xue Bao J. Appl. Ecol. 2009, 20, 1383-1389. 
75. McBride, M.B. Environmental Chemistry of Soils; Oxford University Press: New York, NY, USA, 1994.

76. Bissen, M.; Frimmel, F.H. Arsenic—A review. Part I: Occurrence, toxicity, speciation, mobility. Acta Hydrochim. Hydrobiol. 2003, 31, 9-18. [CrossRef]

77. Kubicki, J.D. Comparison of As (III) and As (V) complexation onto Al-and Fe-hydroxides. Adv. Arsen. Res. Integr. Exp. Obs. Stud. Implic. Migr. 2005, 915, 104-117.

78. Marschner, H. Mineral Nutrition of Higher Plants, 2nd ed.; Academic Press: London, UK, 1995.

79. Manning, B.A.; Goldberg, S. Modeling competitive adsorption of arsenate with phosphate and molybdate on oxide minerals. Soil Sci. Soc. Am. J. 1996, 60, 121-131. [CrossRef]

80. Violante, A.; Pigna, M. Competitive sorption of arsenate and phosphate on different clay minerals and soils. Soil Sci. Soc. Am. J. 2002, 66, 1788-1796. [CrossRef]

81. Vetterlein, D.; Szegedi, K.; Ackermann, J.; Mattusch, J.; Neue, H.U.; Tanneberg, H.; Jahn, R. Competitive mobilization of phosphate and arsenate associated with goethite by root activity. J. Environ. Qual. 2007, 36, 1811-1820. [CrossRef]

82. Koo, N.; Kim, M.-S.; Hyun, S.; Kim, J.-G. Effects of the incorporation of phosphorus and iron into arsenic-spiked artificial soils on root growth of lettuce using response surface methodology. Commun. Soil Sci. Plant Anal. 2013, 44, 1259-1271. [CrossRef]

83. Woolson, E. Arsenic phytotoxicity and uptake in six vegetable crops. Weed Sci. 1973, 21, 524-527. [CrossRef]

84. Jacobs, L.; Keeney, D. Arsenic-phosphorus interactions on corn. Commun. Soil Sci. Plant Anal. 1970, 1, 85-93. [CrossRef]

85. Pigna, M.; Cozzolino, V.; Giandonato Caporale, A.; Mora, M.; Di Meo, V.; Jara, A.; Violante, A. Effects of phosphorus fertilization on arsenic uptake by wheat grown in polluted soils. J. Soil Sci. Plant Nutr. 2010, 10, 428-442. [CrossRef]

86. Mwamila, L. Arsenic (V) and Phosphate Sorption to Swedish Clay Soils-Freundlich Sorption Modelling (Civil Project). 2011. Available online: https:// projectabstracts.com/6951/arsenic-v-and-phosphate-sorption-to-swedish-clay-soils-freundlichsorption-modelling.html (accessed on 1 May 2021).

87. Desta, M.B. Batch sorption experiments: Langmuir and Freundlich isotherm studies for the adsorption of textile metal ions onto teff straw (Eragrostis tef) agricultural waste. J. Thermodyn. 2013, 2013, 6. [CrossRef]

88. Smith, A.H.; Lopipero, P.A.; Bates, M.N.; Steinmaus, C.M. Arsenic Epidemiology and Drinking Water Standards; American Association for the Advancement of Science: Washington, DC, USA, 2002.

89. Geng, C.; Zhu, Y.; Tong, Y.; Christie, P. Uptake and translocation of arsenic and phosphorus in pho2 mutant and wild type of Arabidopsis thaliana. J. Plant Nutr. 2005, 28, 1323-1336. [CrossRef]

90. Deng, D.; Wu, S.-C.; Wu, F.-Y.; Deng, H.; Wong, M.-H. Effects of root anatomy and Fe plaque on arsenic uptake by rice seedlings grown in solution culture. Environ. Pollut. 2010, 158, 2589-2595. [CrossRef] [PubMed]

91. Liu, W.; Zhu, Y.; Smith, F.; Smith, S. Do iron plaque and genotypes affect arsenate uptake and translocation by rice seedlings (Oryza sativa L.) grown in solution culture? J. Exp. Bot. 2004, 55, 1707-1713. [CrossRef]

92. Quéméneur, M.; Cébron, A.; Billard, P.; Battaglia-Brunet, F.; Garrido, F.; Leyval, C.; Joulian, C. Population structure and abundance of arsenite-oxidizing bacteria along an arsenic pollution gradient in waters of the Upper Isle River Basin, France. Appl. Environ. Microbiol. 2010, 76, 4566-4570. [CrossRef] [PubMed]

93. Rahman, M.A.; Hasegawa, H. High levels of inorganic arsenic in rice in areas where arsenic-contaminated water is used for irrigation and cooking. Sci. Total Environ. 2011, 409, 4645-4655. [CrossRef] [PubMed]

94. Koseki, K. Suppression of arsenic injury of rice plants by the application of higher phosphate concentration in culture solution. Sci. Rep. Miyagi Agric. Coll. 1988, 36, 15-21.

95. Lu, Y.; Dong, F; Deacon, C.; Chen, H.-j; Raab, A.; Meharg, A.A. Arsenic accumulation and phosphorus status in two rice (Oryza sativa L.) cultivars surveyed from fields in South China. Environ. Pollut. 2010, 158, 1536-1541. [CrossRef]

96. Singh, A.K. Engineered Nanoparticles: Structure, Properties and Mechanisms of Toxicity; Academic Press: Cambridge, MA, USA, 2015.

97. Zhao, F.J.; Ma, J.F.; Meharg, A.; McGrath, S. Arsenic uptake and metabolism in plants. New Phytol. 2009, 181, 777-794. [CrossRef] [PubMed]

98. Raghothama, K. Phosphate acquisition. Annu. Rev. Plant Biol. 1999, 50, 665-693. [CrossRef] [PubMed]

99. Liu, F.; Chang, X.-J.; Ye, Y.; Xie, W.-B.; Wu, P.; Lian, X.-M. Comprehensive sequence and whole-life-cycle expression profile analysis of the phosphate transporter gene family in rice. Mol. Plant 2011, 4, 1105-1122. [CrossRef] [PubMed]

100. Paszkowski, U.; Kroken, S.; Roux, C.; Briggs, S.P. Rice phosphate transporters include an evolutionarily divergent gene specifically activated in arbuscular mycorrhizal symbiosis. Proc. Natl. Acad. Sci. USA 2002, 99, 13324-13329. [CrossRef] [PubMed]

101. Wang, D.; Lv, S.; Jiang, P.; Li, Y. Roles, regulation, and agricultural application of plant phosphate transporters. Front. Plant Sci. 2017, 8, 817. [CrossRef] [PubMed]

102. Sun, S.; Gu, M.; Cao, Y.; Huang, X.; Zhang, X.; Ai, P.; Zhao, J.; Fan, X.; Xu, G. A constitutive expressed phosphate transporter, OsPht1; 1, modulates phosphate uptake and translocation in phosphate-replete rice. Plant Physiol. 2012, 159, 1571-1581. [CrossRef]

103. Zhang, F.; Sun, Y.; Pei, W.; Jain, A.; Sun, R.; Cao, Y.; Wu, X.; Jiang, T.; Zhang, L.; Fan, X. Involvement of O s P ht1; 4 in phosphate acquisition and mobilization facilitates embryo development in rice. Plant J. 2015, 82, 556-569. [CrossRef]

104. Ai, P.; Sun, S.; Zhao, J.; Fan, X.; Xin, W.; Guo, Q.; Yu, L.; Shen, Q.; Wu, P.; Miller, A.J. Two rice phosphate transporters, OsPht1; 2 and OsPht1; 6, have different functions and kinetic properties in uptake and translocation. Plant J. 2009, 57, 798-809. [CrossRef]

105. Jia, H.; Ren, H.; Gu, M.; Zhao, J.; Sun, S.; Zhang, X.; Chen, J.; Wu, P.; Xu, G. The phosphate transporter gene OsPht1; 8 is involved in phosphate homeostasis in rice. Plant Physiol. 2011, 156, 1164-1175. [CrossRef] [PubMed] 
106. Kamiya, T.; Islam, R.; Duan, G.; Uraguchi, S.; Fujiwara, T. Phosphate deficiency signaling pathway is a target of arsenate and phosphate transporter OsPT1 is involved in As accumulation in shoots of rice. Soil Sci. Plant Nutr. 2013, 59, 580-590. [CrossRef]

107. Gu, M.; Chen, A.; Sun, S.; Xu, G. Complex regulation of plant phosphate transporters and the gap between molecular mechanisms and practical application: What is missing? Mol. Plant 2016, 9, 396-416. [CrossRef]

108. Camara, A.Y.; Wan, Y.; Yu, Y.; Wang, Q.; Li, H. Effect of selenium on uptake and translocation of arsenic in rice seedlings (Oryza sativa L.). Ecotoxicol. Environ. Saf. 2018, 148, 869-875. [CrossRef]

109. Schwarz, K.; Foltz, C.M. Selenium as an integral part of factor 3 against dietary necrotic liver degeneration. J. Am. Chem. Soc. 1957, 79, 3292-3293. [CrossRef]

110. Moulick, D.; Ghosh, D.; Santra, S.C. Evaluation of effectiveness of seed priming with selenium in rice during germination under arsenic stress. Plant Physiol. Biochem. 2016, 109, 571-578. [CrossRef] [PubMed]

111. Pokhrel, G.R.; Wang, K.T.; Zhuang, H.; Wu, Y.; Chen, W.; Lan, Y.; Zhu, X.; Li, Z.; Fu, F.; Yang, G. Effect of selenium in soil on the toxicity and uptake of arsenic in rice plant. Chemosphere 2020, 239, 124712. [CrossRef]

112. Roman, M.; Jitaru, P.; Barbante, C. Selenium biochemistry and its role for human health. Metallomics 2014, 6, 25-54. [CrossRef] [PubMed]

113. Zhao, X.Q.; Mitani, N.; Yamaji, N.; Shen, R.F.; Ma, J.F. Involvement of silicon influx transporter OsNIP2; 1 in selenite uptake in rice. Plant Physiol. 2010, 153, 1871-1877. [CrossRef]

114. Chen, T.; Wong, Y.-S. Selenocystine induces reactive oxygen species-mediated apoptosis in human cancer cells. Biomed. Pharmacother. 2009, 63, 105-113. [CrossRef] [PubMed]

115. Carroll, L.; Davies, M.; Pattison, D. Reaction of low-molecular-mass organoselenium compounds (and their sulphur analogues) with inflammation-associated oxidants. Free Radic. Res. 2015, 49, 750-767. [CrossRef] [PubMed]

116. Chauhan, R.; Awasthi, S.; Indoliya, Y.; Chauhan, A.S.; Mishra, S.; Agrawal, L.; Srivastava, S.; Dwivedi, S.; Singh, P.C.; Mallick, S. Transcriptome and proteome analyses reveal selenium mediated amelioration of arsenic toxicity in rice (Oryza sativa L.). J. Hazard. Mater. 2020, 390, 122122. [CrossRef]

117. Pezzarossa, B.; Remorini, D.; Gentile, M.L.; Massai, R. Effects of foliar and fruit addition of sodium selenate on selenium accumulation and fruit quality. J. Sci. Food Agric. 2012, 92, 781-786. [CrossRef] [PubMed]

118. Brown, M.L. Present knowledge in nutrition. Int. Life Sci. Inst.-Nutr. Found. 1990.

119. Terry, N.; Zayed, A.; De Souza, M.; Tarun, A. Selenium in higher plants. Annu. Rev. Plant Biol. 2000, 51, 401-432. [CrossRef]

120. Hartikainen, H. Biogeochemistry of selenium and its impact on food chain quality and human health. J. Trace Elem. Med. Biol. 2005, 18, 309-318. [CrossRef] [PubMed]

121. Feng, R.; Wei, C.; Tu, S. The roles of selenium in protecting plants against abiotic stresses. Environ. Exp. Bot. 2013, 87, 58-68. [CrossRef]

122. Turakainen, M.; Hartikainen, H.; Seppänen, M.M. Effects of selenium treatments on potato (Solanum tuberosum L.) growth and concentrations of soluble sugars and starch. J. Agric. Food Chem. 2004, 52, 5378-5382. [CrossRef] [PubMed]

123. Zhang, L.; Hu, B.; Li, W.; Che, R.; Deng, K.; Li, H.; Yu, F.; Ling, H.; Li, Y.; Chu, C. Os PT 2, a phosphate transporter, is involved in the active uptake of selenite in rice. New Phytol. 2014, 201, 1183-1191. [CrossRef]

124. Schiavon, M.; Pilon-Smits, E.A. Selenium biofortification and phytoremediation phytotechnologies: A review. J. Environ. Qual. 2017, 46, 10-19. [CrossRef] [PubMed]

125. Li, H.F.; McGrath, S.P.; Zhao, F.J. Selenium uptake, translocation and speciation in wheat supplied with selenate or selenite. New Phytol. 2008, 178, 92-102. [CrossRef]

126. Pandey, C.; Gupta, M. Selenium and auxin mitigates arsenic stress in rice (Oryza sativa L.) by combining the role of stress indicators, modulators and genotoxicity assay. J. Hazard. Mater. 2015, 287, 384-391. [CrossRef]

127. Ghosh, S.; Saha, J.; Biswas, A.K. Interactive influence of arsenate and selenate on growth and nitrogen metabolism in wheat (Triticum aestivum L.) seedlings. Acta Physiol. Plant. 2013, 35, 1873-1885. [CrossRef]

128. Couture, R.M.; Sekowska, A.; Fang, G.; Danchin, A. Linking selenium biogeochemistry to the sulfur-dependent biological detoxification of arsenic. Environ. Microbiol. 2012, 14, 1612-1623. [CrossRef] [PubMed]

129. Goh, K.-H.; Lim, T.-T. Geochemistry of inorganic arsenic and selenium in a tropical soil: Effect of reaction time, $\mathrm{pH}$, and competitive anions on arsenic and selenium adsorption. Chemosphere 2004, 55, 849-859. [CrossRef]

130. Afton, S.E.; Catron, B.; Caruso, J.A. Elucidating the selenium and arsenic metabolic pathways following exposure to the non-hyperaccumulating Chlorophytum comosum, spider plant. J. Exp. Bot. 2009, 60, 1289-1297. [CrossRef]

131. Zwolak, I. The role of selenium in arsenic and cadmium toxicity: An updated review of scientific literature. Biol. Trace Elem. Res. 2020, 193, 44-63. [CrossRef] [PubMed]

132. Chauhan, R.; Awasthi, S.; Tripathi, P.; Mishra, S.; Dwivedi, S.; Niranjan, A.; Mallick, S.; Tripathi, P.; Pande, V.; Tripathi, R.D. Selenite modulates the level of phenolics and nutrient element to alleviate the toxicity of arsenite in rice (Oryza sativa L.). Ecotoxicol. Environ. Saf. 2017, 138, 47-55. [CrossRef]

133. Kaur, S.; Singh, D.; Singh, K. Effect of selenium application on arsenic uptake in rice (Oryza sativa L.). Environ. Monit. Assess. 2017, 189, 1-8. [CrossRef] [PubMed]

134. Pandey, C.; Gupta, M. Selenium amelioration of arsenic toxicity in rice shows genotypic variation: A transcriptomic and biochemical analysis. J. Plant Physiol. 2018, 231, 168-181. [CrossRef] [PubMed] 
135. El-Ramady, H.R.; Domokos-Szabolcsy, É.; Shalaby, T.A.; Prokisch, J.; Fári, M. Selenium in agriculture: Water, air, soil, plants, food, animals and nanoselenium. $\mathrm{CO}_{2}$ Sequestration Biofuels Depollut. 2015, 5, 153-232.

136. Sharma, S.; Kaur, N.; Kaur, S.; Nayyar, H. Selenium as a nutrient in biostimulation and biofortification of cereals. Indian J. Plant Physiol. 2017, 22, 1-15. [CrossRef]

137. Camara, A.Y.; Wan, Y.; Yu, Y.; Wang, Q.; Wang, K.; Li, H. Effect of endogenous selenium on arsenic uptake and antioxidative enzymes in as-exposed rice seedlings. Int. J. Environ. Res. Public Health 2019, 16, 3350. [CrossRef]

138. Thor, K. Calcium-Nutrient and messenger. Front. Plant Sci. 2019, 10, 440. [CrossRef]

139. Mahajan, S.; Pandey, G.K.; Tuteja, N. Calcium-and salt-stress signaling in plants: Shedding light on SOS pathway. Arch. Biochem. Biophys. 2008, 471, 146-158. [CrossRef]

140. Parvin, K.; Nahar, K.; Hasanuzzaman, M.; Bhuyan, M.B.; Fujita, M. Calcium-mediated growth regulation and abiotic stress tolerance in plants. In Plant Abiotic Stress Tolerance; Springer: Berlin/Heidelberg, Germany, 2019; pp. 291-331.

141. Upadhyaya, H.; Begum, L.; Dey, B.; Nath, P.; Panda, S. Impact of calcium phosphate nanoparticles on rice plant. J. Plant Sci. Phytopathol. 2017, 1, 1-10.

142. Lutts, S.; Kinet, J.; Bouharmont, J. Effects of salt stress on growth, mineral nutrition and proline accumulation in relation to osmotic adjustment in rice (Oryza sativa L.) cultivars differing in salinity resistance. Plant Growth Regul. 1996, 19, 207-218. [CrossRef]

143. Asano, T.; Hayashi, N.; Kobayashi, M.; Aoki, N.; Miyao, A.; Mitsuhara, I.; Ichikawa, H.; Komatsu, S.; Hirochika, H.; Kikuchi, S. A rice calcium-dependent protein kinase OsCPK12 oppositely modulates salt-stress tolerance and blast disease resistance. Plant $J$. 2012, 69, 26-36. [CrossRef]

144. Wilkins, K.A.; Matthus, E.; Swarbreck, S.M.; Davies, J.M. Calcium-mediated abiotic stress signaling in roots. Front. Plant Sci. 2016, 7, 1296. [CrossRef] [PubMed]

145. Ahmad, P.; Sarwat, M.; Bhat, N.A.; Wani, M.R.; Kazi, A.G.; Tran, L.-S.P. Alleviation of cadmium toxicity in Brassica juncea L. (Czern. \& Coss.) by calcium application involves various physiological and biochemical strategies. PLoS ONE 2015, 10, e0114571.

146. Trewavas, A.J.; Malhó, R. Ca ${ }^{2+}$ signalling in plant cells: The big network! Curr. Opin. Plant Biol. 1998, 1, 428-433. [CrossRef]

147. Pandey, S.; Zhang, W.; Assmann, S.M. Roles of ion channels and transporters in guard cell signal transduction. FEBS Lett. 2007, 581, 2325-2336. [CrossRef]

148. Sanders, D.; Pelloux, J.; Brownlee, C.; Harper, J.F. Calcium at the crossroads of signaling. Plant Cell 2002, 14, S401-S417. [CrossRef] [PubMed]

149. Luan, S.; Kudla, J.; Rodriguez-Concepcion, M.; Yalovsky, S.; Gruissem, W. Calmodulins and calcineurin B-like proteins: Calcium sensors for specific signal response coupling in plants. Plant Cell 2002, 14, S389-S400. [CrossRef] [PubMed]

150. Manivannan, P.; Jaleel, C.A.; Sankar, B.; Somasundaram, R.; Murali, P.V.; Sridharan, R.; Panneerselvam, R. Salt stress mitigation by calcium chloride in Vigna radiata (L.) Wilczek. Acta Biol. Crac. Ser. Bot. 2007, 49, 105-109.

151. Olyaie, E.; Banejad, H.; Afkhami, A.; Rahmani, A.; Khodaveisi, J. Development of a cost-effective technique to remove the arsenic contamination from aqueous solutions by calcium peroxide nanoparticles. Sep. Purif. Technol. 2012, 95, 10-15. [CrossRef]

152. Fuessle, R.W.; Taylor, M.A. Stabilization of arsenite wastes with prior oxidation. J. Environ. Eng. 2004, 130, 1063-1066. [CrossRef]

153. Liu, C.-p.; Luo, C.-1.; Xu, X.-h.; Wu, C.-a.; Li, F.-b.; Zhang, G. Effects of calcium peroxide on arsenic uptake by celery (Apium graveolens L.) grown in arsenic contaminated soil. Chemosphere 2012, 86, 1106-1111. [CrossRef] [PubMed]

154. Chou, M.-L.; Jean, J.-S.; Yang, C.-M.; Hseu, Z.-Y.; Chen, Y.-H.; Wang, H.-L.; Das, S.; Chou, L.-S. Inhibition of ethylenediaminetetraacetic acid ferric sodium salt (EDTA-Fe) and calcium peroxide $\left(\mathrm{CaO}_{2}\right)$ on arsenic uptake by vegetables in arsenic-rich agricultural soil. J. Geochem. Explor. 2016, 163, 19-27. [CrossRef]

155. Walawska, B.; Gluzińska, J.; Miksch, K.; Turek-Szytow, J. Solid inorganic peroxy compounds in environmental protection. Pol. J. Chem. Technol. 2007, 9, 68-72. [CrossRef]

156. Syu, C.-H.; Yu, C.-H.; Lee, D.-Y. Effect of applying calcium peroxide on the accumulation of arsenic in rice plants grown in arsenic-elevated paddy soils. Environ. Pollut. 2020, 266, 115140. [CrossRef]

157. Qian, Y.; Zhou, X.; Zhang, Y.; Zhang, W.; Chen, J. Performance and properties of nanoscale calcium peroxide for toluene removal. Chemosphere 2013, 91, 717-723. [CrossRef] [PubMed]

158. Zhai, J.; Jiang, C.H. Synthesis of calcium peroxide microparticles and its application in glyphosate wastewater pretreatment. In Proceedings of Advanced Materials Research; Trans Tech Publications Ltd.: Freienbach, Switzerland, 2014; pp. $1139-1143$.

159. Rahman, A.; Mostofa, M.G.; Alam, M.; Nahar, K.; Hasanuzzaman, M.; Fujita, M. Calcium mitigates arsenic toxicity in rice seedlings by reducing arsenic uptake and modulating the antioxidant defense and glyoxalase systems and stress markers. BioMed Res. Int. 2015, 2015, 340812. [CrossRef] [PubMed]

160. Romeis, T.; Ludwig, A.A.; Martin, R.; Jones, J.D. Calcium-dependent protein kinases play an essential role in a plant defence response. EMBO J. 2001, 20, 5556-5567. [CrossRef] [PubMed]

161. Siddiqui, M.H.; Alamri, S.; Khan, M.N.; Corpas, F.J; Al-Amri, A.A.; Alsubaie, Q.D.; Ali, H.M.; Kalaji, H.M.; Ahmad, P. Melatonin and calcium function synergistically to promote the resilience through ROS metabolism under arsenic-induced stress. J. Hazard. Mater. 2020, 398, 122882. [CrossRef]

162. Zhai, W.; Zhao, W.; Yuan, H.; Guo, T.; Hashmi, M.Z.; Liu, X.; Tang, X. Reduced Cd, Pb, and As accumulation in rice (Oryza sativa L.) by a combined amendment of calcium sulfate and ferric oxide. Environ. Sci. Pollut. Res. 2020, 27, 1348-1358. [CrossRef] [PubMed]

163. Wu, J.; Huang, D.; Liu, X.; Meng, J.; Tang, C.; Xu, J. Remediation of As (III) and Cd (II) co-contamination and its mechanism in aqueous systems by a novel calcium-based magnetic biochar. J. Hazard. Mater. 2018, 348, 10-19. [CrossRef] [PubMed] 